\title{
The Prospects of Intercultural Education in Bosnia and Herzegovina Elvira Islamović ${ }^{*}$ Nermina Blažević
}

\begin{abstract}
Throughout history, education has not only been a carrier of culture, but also an integral part of communication between different cultures. Challenges faced by educational and cultural institutions in most modern pluralistic societies are higher than in earlier societies. The legacy of ethnic conflict in the war in Bosnia and Herzegovina, in which traditional value of multicultural and multireligious life was undermined, had immediate implications for social, cultural and educational policies. Educational policy, based on the assumption of a national culture that promotes national exclusivity through textbooks and educational practice, should overcome in recognition of cultural diversity and dialogue in a globalized world where differences should be considered an advantage and not deemed an obstacle to common life and cooperation. The paper highlights the importance of introducing interculturalism as an important component of the overall educational practice. Teaching the value of diversity, the affirmation of universal values that underlie a democratic society, a sense of responsibility to themselves and to each other, the rejection of exclusion and differentiation of others on any basis, solidarity and cooperation, are current issues of the modern pedagogical and sociological discourse. These concerns must receive a stronger affirmation and application in the educational process of Bosnia and Herzegovina.
\end{abstract}

Keywords: Cultural Diversity; Bosnian Society; Intercultural Education

\footnotetext{
* Corresponding authors: Elvira Islamović and Nermina Blažević; Masaryk University; e-mail: nermina_blazevic@yahoo.com
} 


\section{Introduction}

Many countries, not just today but also in the past were culturally pluralistic and socially divided. Changes taking place in the modern globalized world developed into the different cultures and societies which became much more interconnected and interdependent. One of the most important problems of these contemporary times is to build mutual trust, cooperation, solidarity, respect for others, and the reduction of social prejudices and stereotypes, such as nationalism, racism, sexism, homophobia, etc. Often highlighted humanistic values such as the protection and promotion of human rights and the values of pluralist democracy, show that their nature is characterized as more declarative, then applied in ,real world.“ Many countries are concerned because of the appearance of violence, racism, xenophobia and an aggressive nationalism that threatens the integration and stability of many societies.

It is generally known that the education and upbringing can cause an increase or reduction of social exclusion and prejudices towards others who are different. Education is an important part of communication that shapes the patterns of behavior between different cultures and enables the development of society and the individual. Challenges faced by educational and cultural institutions, in most modern pluralistic societies, are higher than in earlier societies. The school plays a decisive role in the process of socialization. The society seeks to develop certain 
values and traits for children emphasizing on them in schools through education.

\section{Cultural Differences: Multicultural or Intercultural}

\section{Education}

Multiculturalism can be described as a way of applying democratic rights in this contemporary diverse world, it is a way of expressing diversities in the society. Cultural diversity and multicultural citizenship can be considered as one of the preconditions for the integration of all in a democratic society. Multiculturalism as a term is used to denote a cultural policy that seeks equal coexistence of cultures and respect of other people's cultures, customs and values. Multicultural public policies seek to improve the social and economic position of minorities of all kinds. In a specific case of Bosnia and Herzegovina multiculturalism could be considered as a key solution for the joint existence of this heterogeneous and multiethnic country. However, such policy implies that multiculturalism also relies on the ethnosocial disparities, ethnic tensions and conflicts (Kukić, 1995, 79).

Multiculturalism as a cultural policy, therefore, arises as a reaction to this fact in order to ensure conditions for the survival of culture in these confronted situations (Kukić, 1995, 79). In particular, it relates to ethnic and racial minorities and Indigenous peoples who have historically been the target of harsh discrimination, oppression and injustice. Multiculturalism, by 
definition, means life next to each other. Multiculturalism is, according to sociologist Kukić, the lowest level of connection between ethnicities which, without disturbing each other, live and coexist in the same territory. The situation is different in the case of inter-culturalism, a cultural policy whose essence is reciprocity, equal and full-fledged exchange, expansion and connectivity among different cultures in a society. Therefore, it is important to highlight that interculturalism rather than multiculturalism is a form of cultural life in multinational and multicultural environments, which has no adequate alternative.

In modern democratic societies, understanding and acceptance of members of different cultures is becoming one of the important and basic roles of the educational system. According to the Brian Barry (2006), a researcher of multicultural process, the term "multicultural education" includes two educational policies that are contrary to its origins and implications. The first assumes that all children should have equal application, regardless of race or ethnicity, gender or sexual orientation, religious beliefs or any other characteristic. The program should be multicultural and inclusive, taking into account the past and present and the position of all the group. Another approach excludes the joint program and advocates for various programs at the school with a "separate clientele." "Normal kids", "normal students" will then live in small closed communities as a rule within the school and school district surrounded by those who for whatever reason are defined as different (p. 285). 
The Council of Europe advocates in the last fifteen years the intercultural education because of the multicultural composition of European countries. The term "intercultural education" is associated with the European tradition of education, as opposed to the "multicultural education," a term which is mainly associated with the Anglo-Saxon countries (Britain, Canada, USA). Although the two terms are often used interchangeably, it is important to distinguish between interculturalism which means interactive links between cultures, dynamic / qualitative dimension of the interactive relationship between cultures and multiculturalism, which indicates the simultaneous existence of multiple cultures in an area, it means "static quantitative dimension of multiculturalism; condition, not a relationship" (Puzić, 2008). The first studies of the Council of Europe on intercultural education were focused on the education of immigrant populations in European schools. At the same time the focus was on learning the language, which was not so emphasized because of the lack of prior education and specific experiences of socialization. However, such programs for "culturally different," served as a means of segregation and stigmatization; not taking into account the relationship between the culture from which they came and the culture of the country of origin. Later, in the 1980s as a major task of intercultural education was provided help to students to acquire a positive selfimage and self-respect. Until the 1990s, the focus was on the issue 
of relations between cultural groups, there was a need to engage in intercultural education and the majority of the children.

White Paper (Council of Europe) on Intercultural Dialogue (2008) argues that one of the five approaches for the promotion of the intercultural dialogue are learning and teaching intercultural competences (in all levels of education) through a various subjects, religion, non-formal and formal education, teacher education and family environment.

Intercultural education includes and assumes:

- Education for empathy - you need to learn to understand others and empathize with them;

- Education for solidarity - requires greater sensitivity to the problems of inequality and social marginalization;

- Education for recognition and respect for diversity - it is necessary to respect different lifestyles as well as personal and social wealth;

- Education against ethnocentrism, nationalism, racism and other factors of discrimination - it is necessary to encourage the development of intercultural sensitivity and awareness of self and others (Piršl, 2008).

Intercultural education involves a holistic and lifelong learning process and focuses on the development of competence and intercultural communication. The presence of the idea of interculturalism in education can be seen in three ways:

1) The declaratory affirmation of the principles and objectives of interculturalism in the law and regulations of education fields;

2) Through a declarative representation of the principles and objectives of interculturalism in the school documentsl;

3) The practical application of these principles and objectives in the schools - the school can be considered as a fertile environment together with teachers with the intercultural competencies (Piršl, 2008). 
Work in an intercultural school environment enables the students and the teachers to feel important, valued and unique; they enjoy their own independent behavior; develop empathy, friendship and respect for each other, encouraging cooperation and individuality of the labor to create the conditions for understanding themselves and communicate their ideas and feelings about themselves and others (Piršl, 2008). Intercultural education based on these settings should result in the development of intercultural identity ("open identity") (Lukic, 2010, 59-75). For most modern contemporary cultural complex societies, it is necessary to develop their own democratic and pluralistic model. Therefore, the establishment of a form of intercultural education for diversity in society is formed for learning and accepting diversities as something valuable. Cultural Pluralism implies mutual understanding, tolerance and dialogue, intertwining all different cultural traits (Spajić-Vrkaš, 2004). According to SpajićVrkaš (2004) notion of interculturalism includes interactive links between cultures, and appeared as a result of having a need to organize multicultural societies according to the principles of cultural pluralism and social dialogue. "It will be valid not only to learn together, but also to live together, what excludes any institutional separation." The co-existence will have to avoid the classic segregationist policies which Bosnian society experience today in our so-called "unified" school system. Therefore the secular schools have to try, at least within the compulsory education, to take into account the diversity of students in 
heterogeneous groups. Students are different, but the goals must be shared, and the basic one is dealing with diversity without exclusion and without separation. Dual society produces dual school. But the dual school is not a school of moral and social education. On the other hand, the "intellectual" coexistence must be strengthened by active common living in joint projects (Legrand, 1995, 61-62).

Education and training institutions are important agents of socialization and therefore stand out as an important factor of the formation and elimination of prejudice and social exclusion. Some courses at the school in particular, can contribute to the creation of social prejudice and irrational interpretations, such as national history, national literature and others, especially if they are relying on legends and myths rather than on the facts. Schools are often accused of not respecting enough diversity. They must show sufficient flexibility between individual and group differences, and also have to bring together individuals around common rules. In order to achieve this, it is important to emphasize the importance of the introduction of interculturalism as an important component of the overall educational practice. Respect for pluralism in education, the recognition of cultural diversity and equality, and the question of maintaining a balance between the necessary integration, while respecting and preserving their own identity, are the questions that encourage many discussions. 


\section{Intercultural Education in Bosnian Context}

Socio-cultural milieu of Bosnia and Herzegovina is marked with interculturalism for centuries. The historical experience of living together in Bosnia and Herzegovina, confirms that it is possible to live together and make the preservation of ethnic and cultural characteristics of each group individually. The nationalist discourse formed during the breakup of Yugoslavia, sought to permanently delete and destroy this longstanding cohabitation among religious and ethnic groups in Bosnia and Herzegovina. Destruction, nationalism and the establishment of ethnic displacement, were aimed at destroying of the collective memory and cultural traditions. The war wanted to destroy all rules which were built in order to make relations with those who are different ethnically. These issues have direct implications in the social, cultural and educational policies even today in Bosnia and Herzegovina.

In the post-socialist and post-war Bosnia and Herzegovina, the key problem of educational systems is their pronounced ethnic nationalist dimension and divisions. Ethnic divisions are an integral part of education, and the implications of the strongest divisions and exclusion are visible through the so-called national group of subjects: language and literature, history, geography and religious education (all of these subjects are named differently depending on ethnic affiliation). "Since the end of communist rule, there are three periods of renewal of curricula: 1990-1992, when the curriculum was nationalized by the three main ethnic 
groups; then in 1992 and by the end of the war in the 1995, when three totally new plans were developed, and post-war period through which three separated curricula were consolidated in education systems. Three types of curricula determine future of education of Bosnian citizens. Firstly, it has to be emphasized that every of these curriculas are national in the sense that they focus on language, culture and history of only their own ethnic group. Positioning of education towards ideological and concealing veil of the ruling parties in order to manipulate, always moves away education systems from its true mission, meaning of the true human emancipation. "What is not successfully carried out during the war, continues to be carried out in these contemporary times through ethnic nationalist separation in the educational system. These "different" education systems promote a particular ideological and political objectives of a certain ethnic group“ (Kapo, 2012, 144). "Education is often abused in practice, giving students different interpretations of the same facts," and "often schools divide students on the basis of their ethnic identity, language and religion" (Pasalic-Kreso, 1999, 7). These disorders are common in places where minority refugees took place and where the education is organized for the purpose of the majority of the population. There were some cases when students and teachers who belong to a minority group were banned and could not even enter the school building because the school curriculum completely ignores the cultural identity of these minority ethnic groups, on the other hand; minority boycotted the majority school 
system and established a parallel one to members of their own ethnic group (Pasalic-Kreso, 2004 , 9-10).

The so-called "two schools under one roof" were formed for the purposes of national homogeneity, segregation and design of exclusively ethnic identity. Educational policy based on the assumption of a national culture, homogenization and ethnic mobilization around cultural symbols and beliefs, which manipulate etnocracy aimed at further separation and segregation of social relations. Two schools under one roof are far away from the social and educational appreciation of ethnic diversity in a globalized world in which differences should be considered as an advantage, not a hindrance to cohabitation and cooperation. Promoting national exclusiveness through textbooks, denying cultural differences, lack of dialogue and mutual cooperation is aimed at raising awareness of ethnicity in order to manipulate ethnic identities for various nationalist projects. Even Bosnia and Herzegovina has reduced the number of segregated schools, however, continue education systems continue to suffer from institutional separation of children by ethnicity and the presence of mono-ethnic schools. National dichotomy is inadequately developed for the multiculturalism and tolerance, which are so necessary for Bosnian society. Building a democratic school that educates the citizen instead of members of the nation or religion should be one of the basic aims for whole Bosnia and Herzegovina. Extracted potentiation on differences as a basic value, exclusivity and manipulation feeling of endangerment of 
others, have long been the only form of policy. Decades behind us left deep wounds for the whole Bosnian society. Bosnia and Herzegovina still confront with the question how to re-learn to live together and to encourage the transformation of public discourse about others.

Political and ideological constraints and exclusivity in Bosnian society during and after the war, did not bypass the educational systems which are supposed to design and to produce cultural uniformity. The education systems in Bosnia and Herzegovina have to be transformed, through the integration of intercultural components in the curricula which has to be unified. With regard to religious, ethnic and cultural diversity that is present in Bosnia and Herzegovina, the question of establishing an intercultural, multilingual education model, which develops integration and democratic connectivity, promotes the tolerance, unity and understanding, stands the question of the survival of Bosnian society. "Schools have the role to explain to young people all the historical, cultural and religious backgrounds of the various ideologies that are scrambling for their attention in a society that surrounds them, or in the school and classroom" (Delors, 1998, 63). Globalized world in which we live, seeks not only to understand the variability of our social position, but to understand the world around us, people and culture that we have and that is different and varies from the interaction. It is essential that school systems and other institutions of education and culture, develop forms of work that will prevent exclusion, nationalism, 
anti-civilization and anti-democratic tendencies, and to promote democratic values, common life and cooperation. Educational institutions must be saved from daily abuse and ideological manipulation. They must be the place where universal human values, human rights and dignities, the value of a pluralistic and democratic society are kept and applied. This educational concept represents an ethical imperative for a society in which the memory of the "ethnic cleansing" is still fresh, and the ominous political message about the impossibility of co-existence of people of different ethnic backgrounds, is still present, unfortunately. The state in which nationalist ideologies teach children and young people cannot live together with each other and the existence of "two schools under one roof" won the important role of education for pluralism, which is based on an understanding and appreciation of other cultures and helps in winning the trust and cooperation. In a democratic society, diversity is seen as an asset, not as a reason for bias or divisions in society.

Because of these reasons, the purpose of education is to prepare individuals not only to shape their own cultural identity and understand their culture, but also to accept, understand and respect other cultures. Discussions on current issues such as multilingual education, the content of school textbooks of history and literature in a multicultural society, are current in Bosnia and Herzegovina which had more effectively the issues of ethnic and national, religious, cultural and linguistic diversity. Already advocated intercultural education could be the approach to this 
problem and could be considered as the best solution. The exit from this Bosnian complex maze requires a greater sensitivity and understanding of ethnic diversity within the educational field, the recognition and appreciation of another, of different children and young people who have to be trained in intercultural communication and action. Indicating the need of shaping public education system that does not suppress the national cultural, linguistic and other characteristics and identities, but only foster civic culture which is common to everyone is the access to educational and cultural aspects of the current Bosnian problem. However, that among other things, requires a change in the political process in the country, but also the change of the education system and the media presentation of different social groups in order to reduce the negative effects of ethnocentrism. It goes without saying, that this is a long social process. Multiculturalism is a complex social phenomenon, often accompanied by tensions and misunderstandings that highlight the differences between certain collectives within society. These conditions represent a growing challenge to the educational and cultural policy.

\section{Conclusion}

Both in the past and today, education enjoys its special role as the main carrier of the culture. Therefore, education has a major role in the dialogue between cultures. It should help to perceive existing social contradictions in a new light, find a way 
out of ethnic exclusion in order to create a pluralistic and democratic civil society. In this sense, it is expected that the educational policies contribute to improved understanding, solidarity and tolerance among individuals, ethnic, social, cultural and religious groups, with the affirmation of knowledge, values, attitudes and skills that lead to human rights and an active commitment to defend those rights. Educational institutions at all levels should encourage reflection, critical distance, intercultural communication and action. Doing so, education institutions may allow the development of sociability and solidarity. For this reason, it is extremely important that schools in Bosnia and Herzegovina as one of the basic educational tasks, encourage the development and awareness of the importance all human rights, intercultural learning and its competence which is necessary to respect cultural differences and pluralism in a multicultural environment. Education should enable the harmonious development of personality with respect to its individuality, social and cultural identity. Equal rights and equal opportunities for optimal development for all students, regardless of their social origin, nationality, religion, the right to education in their mother tongue, the right to choose schools, freedom to choose their individual educational programs, language learning, teaching religious education, a fundamental principle of education must be strongly emphasized in the educational system of Bosnia and Herzegovina. 


\section{References}

Bauman, Z. 1995. Life in Fragments. Cambridge: Polity Press.

Barry, B. 2006. Kultura i jednakost. Egalitarna kritika multikulturalizma. Zagreb: Naklada Jesenski i Turk.

Delors, J. (ur.) 1998. Učenje: blago u nama: Izvješće UNESCO-u Međunarodnog povjerenstva za razvoj obrazovanja za 21. stoljeće. Zagreb: Educa.

Kapo, M. 2012. Nacionalizam $i$ obrazovanje: Studija slučaja Bosne $i$ Hercegovine. Sarajevo: Program podrške obrazovanju. Fond otvoreno društvo Bosna i Hercegovina.

Kukić, S. 1995. Sociologija. Mostar: HKD Napredak.

Legrand, L. 1995. Moralna izobrazba danas, Ima li to smisla? Zagreb: Educa.

Lukić, N. 2010. Identitetni i interkulturalni odgoj i obrazovanje u Hrvatskoj. U: Obrazovanje mladih za ljudska prava i demokratsko građanstvo. Mreža mladih Hrvatske. Studiji o mladima i za mlade. Zagreb: Nacionalna zaklada za razvoj civilnoga društva, 59-75.

Pašalić-Kreso, A. 2003. Geneza sazrijevanja ideje inkluzije ili inkluzija u funkciji smanjivanja neravnopravnosti u obrazovanju. U: PašalićKreso, A., Bevanda, M. et al. (ur.), Inkluzija u školstvu Bosne i Hercegovine. Put prevazilaženja neravnopravnosti u odgoju i obrazovanju. Zbornik radova. Sarajevo: TEPD - Teacher Education and Professional Development i Odsjek za pedagogiju FF u Sarajevu.

Piršl, E. 2008. Interkulturalni odgoj i obrazovanje. Pula: Sveučilište Jurja Dobrile. www.ffpu.hr/fileadmin/Dokumenti/Interkulturalni_odgoj.ppt (20. 9. 2012.).

Puzić, S. 2008. Intercultural education in the European Contex: Analysis of selected European Curricula. Metodika, 15: 390-407.

Spajić-Vrkaš, V. 2004. The emergence of multiculturalism in education: From ignorance to seperation through recognition. U: Mesić, M. (ur.) Experience and Perspectives of Multiculturalism: Croatia in Comparison to Other Multicultural Societies. Zagreb: FFPress i Croation Commission for UNESCO, 87-101. 